\title{
Influence of cutting type and size on rooting of Lavandula dentata L.
}

\author{
BONA, C.M. ${ }^{1 *}$; BIASETTO, I.R. ${ }^{2}$; MASETTO, M. ${ }^{2}$; DESCHAMPS, C. ${ }^{2}$; BIASI, L.A. ${ }^{2}$ \\ ${ }^{1}$ Instituto Agronômico do Paraná (IAPAR), Pólo Regional de Curitiba, Centro Administrativo do Governo do Estado. \\ Rua Máximo João Kopp, 274, Bloco 1, Ala Sul, CEP:82630-900, Curitiba-Brasil *debona@iapar.br ${ }^{2}$ Departamento \\ de Fitotecnia e Fitossanitarismo, Universidade Federal do Paraná, Caixa Postal 19061, CEP: 81531-990, Curitiba- \\ Brasil
}

\begin{abstract}
Even though the Lavandula species may be propagated by seeds, it should not be the preferred propagation method because it causes a great lack of uniformity. On the other hand, asexually propagated lavender crops would provide more homogeneous crops, and clones from high quality plant material would increase the odds for obtaining a higher quality essential oil. However, problems such as poor rooting and restrict market availability for superior clones have been a problem in vegetative propagation of the Lavandula species. The objective of this work was to define which type and size of cutting is more adequate for cutting propagation of $L$. dentata, a very productive Lavandula species. Cuttings with $5,8,10$ or $13 \mathrm{~cm}$ and from the apical or basal parts of stems cut from $L$. dentata stock plants were placed in Plantmax $\mathrm{HT}^{\circledast}$ filled polystyrene foam trays and kept under intermittent mist system for two months. Averages of root number, length of the longest root, fresh and dry root weight, and percentage of rooting were evaluated. Apical cuttings combined $97.9 \%$ rooting with an average of 13.2 roots per cutting and basal cuttings $93.7 \%$ rooting with 2.98 roots per cutting. Apical cuttings with at least $10 \mathrm{~cm}$ in length were considered the most adequate for cutting propagation of $L$. dentata.
\end{abstract}

Key words: vegetative propagation, lavender, medicinal plant

RESUMO: Influência do tipo e tamanho de estaca no enraizamento de Lavandula dentata L. Apesar de serem propagadas por sementes, as espécies de Lavandula deveriam ser preferencialmente propagadas por estaquia devido a grande falta de uniformidade causada pela primeira, enquanto que a propagação assexual da alfazema permite maior homogeneidade da lavoura e o uso de clones de alta qualidade aumentaria as chances de se obter óleo essencial de alta qualidade. No entanto, o baixo poder de enraizamento e o mercado restrito de clones superiores têm sido problemas para a propagação vegetativa de espécies de alfazema. O objetivo deste trabalho foi definir qual tipo e tamanho de estaca seriam mais adequados para a propagação de L. dentata, espécie muito produtiva de Lavandula, por estaquia. Estacas com $5,8,10$ ou $13 \mathrm{~cm}$ das partes apical e basal de ramos de plantas matrizes de $L$. dentata foram colocados em bandejas de isopor com o substrato Plantmax $\mathrm{HT}^{\circledR}$ e mantidas em casa de vegetação sob nebulização por dois meses. As médias de número de raízes, comprimento da raiz mais longa, massa fresca e seca de raízes e porcentagem de enraizamento foram avaliadas. Estacas apicais apresentaram enraizamento de $97,9 \%$ e 13,2 raízes por estaca em média e as estacas basais $93,7 \%$ de enraizamento e 2,98 raízes por estaca. Estacas apicais com pelo menos $10 \mathrm{~cm}$ de comprimento foram consideradas as mais adequadas para a propagação da $L$. dentata por estaquia.

Palavras-chave: propagação vegetativa, alfazema, planta medicinal

\section{INTRODUCTION}

Lavender, Lavandula genus, is a perennial shrub of the Labiaceae family (Cavanagh \& Wilkinson, 2002). The species from the genera are original from Europe but are currently grown in temperate climate regions around the world. The lavender essential oil is very important economically and there is a huge world demand for it (Hughes, 1998). The lavender essential oil is used for the production of high price perfumes, fragrances and essences, in pharmaceutical products, and also in the cosmetic

Recebido para publicação em 01/07/2009

Aceito para publicação em 21/03/2012

Rev. Bras. PI. Med., Botucatu, v.14, n.1, p.8-11, 2012. 
and food industries due to its phenolic metabolites (Singh et al., 1997; Al-Amier et al., 1999; Shellie et al., 2002; Moss et al., 2003; Chemat et al., 2006; Dob et al., 2006). Nevertheless, commercial oil composition presents great content variation, in part due to genetic differences among plant populations since lavender crops have been mostly propagated by seeds and problems such as low secondary metabolites synthesis and great variability among species are ruling (Nogueira \& Romano, 2002). Even tough Lavandula species may be propagated by seeds it should not be the preferred propagation method because it causes great lack of uniformity while asexually propagated lavender crops would provide more homogeneous crops, and clones from high quality would increase the odds of obtaining higher quality essential oil (Tyub et al., 2007). However, poor rooting and restrict market availability for superior clones of Lavandula species have been problems (Calvo \& Segura, 1989).

L. angustifolia angustifolia P. Mill. (English lavender), formerly known as $L$. vera or $L$. officinallis, is practically free from camphor, differently from other species in the genus, however, it is less productive (Cavanagh \& Wilkinson, 2002; Floreno, 1997). L. dentate is rich in 1,8-cineol and fenchol, presents higher camphor content, however it is much more productive than L. angustifolia (Echeverrigaray et al., 2005).

Cutting type (original position on stem of plant stock) may influence the rooting capacity of the cutting. Apical cuttings are less lignified than basal cuttings, have many meristematic cells, which are actively growing, and presents less or none phenolic compounds (Hartmann et al., 2002). However, apical cuttings tend to lose humidity more easily than basal cuttings and extra care, a mist system for example, is required in order keep those cuttings hydrated (Lima et al., 2006). Not only type but size of cuttings matters because of the amount of carbohydrates and nutrients held in the plant tissue, however, larger cuttings means larger evaporation areas as well, and may suffer more dehydration because of it (Hartmann et al., 2002).

The objective of this work was to define which type and size of cutting is more adequate for cutting propagation of $L$. dentata, a very productive Lavandula species.

\section{MATERIAL AND METHOD Influence of cutting size on rooting}

Cuttings with 5, 8, 10 or $13 \mathrm{~cm}$ in length were made from stems detached on August of 2007, from L. dentata stock plants located at the Canguiri Experimental Station of the Federal University of Parana, in Pinhais, PR, Brazil, and placed in Plantmax $\mathrm{HT}^{\circledR}$ filled polystyrene foam trays which were kept under intermittent mist system. A voucher specimen was deposited in the herbarium of the UFPR's Department of Botany (voucher specimen no. UPCB 61.305). A total of 96 cuttings (eight cuttings per treatment and three replications) were used. A completely randomized experimental design was applied. After two months, averages of root number, length of the longest root, fresh and dry root weight, and percentage of rooting were evaluated.

\section{Influence of cutting type on rooting}

Cuttings with $10 \mathrm{~cm}$ in length were removed from apical and basal part of stems detached from $L$. dentata stock plants located at the Canguiri Experimental Station of the Federal University of Parana, in Pinhais, PR, Brazil, and placed in Plantmax $H T^{\circledR}$ filled polystyrene foam trays which were kept under intermittent mist system. A total of 74 cuttings (eight cuttings per treatment and four replications) were used. A completely randomized experimental design was applied. After two months, averages of root number, length of the longest root, fresh and dry root weight, and percentage of rooting were evaluated. test $(p<0.05)$.

Data were submitted to ANOVA and Tukey

\section{RESULT AND DISCUSSION}

\section{Influence of cutting size on rooting}

Size did not influence rooting percentage, which was $100 \%$. Average root number was statistically lower on $5 \mathrm{~cm}$ long cuttings compared to the larger ones, specially the 10 and $13 \mathrm{~cm}$ long cuttings, which produced significant heavier roots (Table 1). This was probably due to the amount of reserves accumulated in different cutting sizes (Hartmann et al., 2002). Similarly to what was observed herein, Costa et al. (2007) preferred longer Ocimum selloi Benth cuttings $(20 \mathrm{~cm})$ than shorter ones $(10 \mathrm{~cm})$ for vigorous vegetative propagation of the species. Biasi \& Costa (2003), working with Lippia alba, also preferred longer $20 \mathrm{~cm}$ cuttings instead of 5,10 or $15 \mathrm{~cm}$, even without mist. Longer cuttings were also considered better than shorter cuttings on propagation of Baccharis stenocephala because they produced more roots (Bona et al., 2004).

In spite of not differing statistically from the $8 \mathrm{~cm}$ long cutting, the average root number on 10 and $13 \mathrm{~cm}$ long cuttings was larger (Table 1), and showed tendency of stabilizing, indicating that $10 \mathrm{~cm}$ long cuttings have the most ideal length to produce adventitious roots, as it requires less plant propagation material and, not as a regular rule (Biasi \& Costa, 2003), larger cuttings may suffer more dehydration (Hartmann et al., 2002).

Roots were longer in the $5 \mathrm{~cm}$ long cuttings, 
TABLE 1. Influence of cutting length on rooting of $L$. dentata.

\begin{tabular}{cccccc}
\hline $\begin{array}{c}\text { Length of cuttings } \\
(\mathbf{c m})\end{array}$ & $\begin{array}{c}\text { Rooting } \\
(\%)\end{array}$ & Root number & \multicolumn{2}{c}{ Root lenght } & \multicolumn{2}{c}{ Fresh weight } & \multicolumn{2}{c}{ Dry weight } \\
\hline 5 & 100 & $10.38 \mathrm{~b}$ & $10.21 \mathrm{a}$ & $1.78 \mathrm{~b}$ & $0.05 \mathrm{~b}$ \\
8 & 100 & $13.92 \mathrm{ab}$ & $7.69 \mathrm{~b}$ & $1.48 \mathrm{~b}$ & $0.11 \mathrm{~b}$ \\
10 & 100 & $16.58 \mathrm{a}$ & $9.11 \mathrm{ab}$ & $2.62 \mathrm{ab}$ & $0.17 \mathrm{ab}$ \\
13 & 100 & $16.58 \mathrm{a}$ & $8.84 \mathrm{ab}$ & $4.94 \mathrm{a}$ & $0.30 \mathrm{a}$ \\
\hline C.V. (\%) & - & 16.48 & 9.28 & 44.17 & 40.32 \\
\hline
\end{tabular}

Average values on same column followed by similar letters do not differ statistically according to Tukey's test at $5 \%$.

TABLE 2. Influence of cutting type on rooting of $L$. dentata.

\begin{tabular}{cccccc}
\hline $\begin{array}{l}\text { Type of cuttings } \\
\text { (position on stem) }\end{array}$ & $\begin{array}{c}\text { Rooting } \\
(\%)\end{array}$ & Root number & $\begin{array}{c}\text { Root lenght } \\
(\mathbf{c m})\end{array}$ & $\begin{array}{c}\text { Fresh weight } \\
(\mathbf{g})\end{array}$ & $\begin{array}{c}\text { Dry weight } \\
(\mathbf{g})\end{array}$ \\
\hline Apical & $97.9 \mathrm{a}$ & $13.12 \mathrm{a}$ & $9.00 \mathrm{a}$ & $1.50 \mathrm{a}$ & $0.12 \mathrm{a}$ \\
Basal & $93.7 \mathrm{a}$ & $2.98 \mathrm{~b}$ & $3.20 \mathrm{~b}$ & $0.39 \mathrm{~b}$ & $0.02 \mathrm{~b}$ \\
C.V. (\%) & 6.30 & 38.75 & 21.48 & 56.95 & 81.31 \\
\hline
\end{tabular}

Average values on same column followed by similar letters do not differ statistically according to Tukey's test at $5 \%$.

however, it did not differ from 10 and $13 \mathrm{~cm}$ long cuttings (Table 1). Anyhow, pruning is usually necessary and very long roots are not ideal for transplantation as breakage or circling roots may form and cause girdling, jeopardizing the perfect functioning of sieve-tube elements, which transports water and solutes upward and downward in the plant (Sadava et al., 2008).

Nevertheless, root number and weight are considered important variables which influence the new plant's survival (Carvalho et al., 2007). Hence, accordingly to results presented in Table 1, if length of stems on stock plants allows it, longer cuttings (10 or $13 \mathrm{~cm}$ long) should be used for propagation of L. dentata.

\section{Influence of cutting type on rooting}

Rooting percentage of apical cuttings was $97.9 \%$ and of basal cuttings $93.7 \%$. The cutting type, i.e., position on stock plant stem, was effective on rooting of $L$. dentata cuttings. In general, apical cuttings were significantly superior to basal cuttings for all variables tested (Table 2). Such outcome was probably due to internal plant hormones such as auxins and other cofactors which are concentrated on plants' apex, where meristematic cells abound (Hartmann et al., 2002). Greater average numbers of longer, heavier roots were obtained. For cutting propagation of $L$. dentata, apical cuttings were considered better than basal cuttings, however, different Lavandula species may respond differently and tests should be performed before choosing the best cutting type for other Lavandula species. Bona et al. (2005) observed different rooting and development responses on different types of Baccharis, a medicinal plant, cuttings. Apical cuttings were better to propagate $B$. articulata and $B$. stenocephala, but to $B$. trimera, cutting type did not matter. However, to Carvalho et al. (2007), basal cuttings of $B$. trimera presented best rooting quality, both in rooting percentage and mass of roots produced. For rooting of another medicinal plant, Ocimum gratissimum L., cuttings removed from basal and middle parts of stems were considered better than the apical cuttings (Sousa et al., 2005); for the vegetative propagation of Hydrangea macrophylla (Thunb.) Ser., an ornamental shrub, basal cuttings were preferentially used (Luz et al., 2007). In 2006, Maia observed the interference of cutting type on cutting propagation of Hyptis suaveolens (L.), an aromatic perennial shrub. Later it was observed that basal and middle stem cuttings presented better performance, but apical cuttings presented better growth during the acclimation process; even thought the species could be propagated independently of the cutting type (Maia et al., 2008).

\section{CONCLUSION}

1) L. dentata cuttings rooted easily.

2) Better rooting response was obtained using apical cuttings with 10 or $13 \mathrm{~cm}$. 


\section{ACKNOWLEDGEMENT}

To CNPq for a Post-Doc scholarship and a Productivity Research Grant to the first and last authors respectively.

\section{REFERENCE}

AL-AMIER, $H$. et al. Tissue culture based screening for selection of high biomass and phenolic producing clonal lines of lavender using Pseudomonas and azetidine-2carboxylate. Journal of Agricultural and Food Chemistry, v.47, n.7, p.2937-43, 1999.

BIASI, L.A.; COSTA, G. Propagação vegetativa de Lippia alba. Ciência Rural, v.33, n.3, p.455-9, 2003.

BONA, C.M. et al. Estaquia de três espécies de Baccharis. Ciência Rural, v.35, n.1, p.223-6, 2005.

BONA, C.M. et al. Propagação de três espécies de carqueja com estacas de diferentes tamanhos. Semina: Ciências Agrárias, v.25, n.3, p.179-84, 2004.

CALVO, M.C.; SEGURA, J. In vitro propagation of lavender. Horticultural Sciences, v.24, p.375-6, 1989.

CARVALHO, R.I.N. et al. Enraizamento de estacas de carqueja em função de diferentes substratos e posições do ramo em plantas masculinas e femininas. Scientia Agraria, v.8, n.3, p.269-74, 2007.

CAVANAGH, H.M.A.; WILKINSON, J.M. Biological activities of lavender essential oil. Phytotherapy Research, v.16, p.301-8, 2002.

CHEMAT, F. et al. Microwave accelerated steam distillation of essential oil from lavender: a rapid, clean and environmentally friendly approach. Analytica Chimica Acta, v.555, n.1, p.157-60, 2006.

COSTA, L.C.B.; PINTO, J.E.B.P.; BERTOLUCCI, S.K.V. Comprimento da estaca e tipo de substrato na propagação vegetativa de atroveran. Ciência Rural, v.37, n.4, p.1157-60, 2007.

DOB, T. et al. Essential oil composition of Lavandula stoechas from Algeria. Pharmaceutical Biology, v.44, n.1, p.60-4, 2006.

ECHEVERRIGARAY, S.; BASSO, R.; ANDRADE, L.B. Micropropagation of Lavandula dentata from axillary buds of field-grown adult plants. Biologia Plantarum, v.49, n.3, p.439-42, 2005.

FLORENO, A. New uses for essential oils could herald wave of growth. Chemical Market Reporter, v.251, n.18, p.24, 1997.
HARTMANN, H.T. et al. Plant propagation: principles and practices. 7.ed. New Jersey: Prentice Hall, 2002. 880p. HUGHES, S. The color purple. Soap, Perfumery \& Cosmetics, v.71, n.8, p.36-8, 1998.

LIMA, R.L.S. et al. Comprimento de estacas e parte do ramo na formação de mudas de aceroleira. Revista Brasileira de Fruticultura, v.28, n.1, p.83-6, 2006.

LUZ, P.B.; PAIVA, P.D.O.; LANDGRAF, P.R.C. Influência de diferentes tipos de estacas e substratos na propagação assexuada de hortênsia [Hydrangea macrophylla (Thunb.) Ser.]. Ciência e Agrotecnologia, v.31, n.3, p.699703, 2007.

MAIA, S.S.S. Propagação, adubação orgânica e níveis de radiação nas características anatômicas e composição de óleo essencial em Hyptis suaveolens (L.) POIT Lamiaceae. 2006. 150p. Tese (Doutorado Área de Concentração em Fitotecnia) - Universidade Federal de Lavras, Lavras.

MAIA, S.S.S. et al. Enraizamento de Hyptis suaveolens (L.) Poit. (Lamiaceae) em função da posição da estaca no ramo. Revista Brasileira de Ciências Agrárias, v.3, n.4, p.317-20, 2008.

MOSS, M. et al. Aromas of rosemary and lavender essential oils differentially affect cognition and mood in healthy adults. International Journal of Neuroscience, v.113, p.15-38, 2003.

NOGUEIRA, J.M.F.; ROMANO, A. Essential oils from micropropagated plants of Lavandula viridis. Phytochemical Analysis, v.13, p.4-7, 2002.

SADAVA, D. et al. Life: the science of biology. 8.ed. Sunderland: Sinauer Associates, 2008. 1121p.

SHELLIE, R. et al. Characterization of lavender essential oils by using gas chromatography - mass spectrometry with correlation of linear retention indices and comparison with comprehensive two-dimensional gas chromatography. Journal of Chromatography, v.970, p.225-34, 2002.

SINGH, A.K. et al. Genetic divergence among 43 lavender (Lavandula officinalis Chaix) clones evaluated over environments. Crop Improvements, v.24, n.1, p.101-4, 1997.

SOUSA, P.B.L.; AYALA-OSUNA, J.T.; GOMES, J.E. Propagação vegetativa de Ocimum gratissimum $\mathrm{L}$. em diferentes substratos. Revista Brasileira de Plantas Medicinais, v.8, n.1, p.39-44, 2005.

TYUB, S.; KAMILI, A.N.; SHAH, A.M. Effect of BAP on shoot regeneration in shoot tip cultures of Lavandula officinalis. Journal of Research \& Development, v.7, p.125-30, 2007. 